\title{
Opioids in cancer: The א-opioid receptor (Review)
}

\author{
QIER ZHOU ${ }^{1}$, ZHIWEI ZHANG ${ }^{2}$, SONGKAI LONG $^{1}$, WANJUN LI ${ }^{1}$, BAIYUN WANG ${ }^{1}$ and NA LIANG ${ }^{1}$ \\ ${ }^{1}$ Department of Anesthesiology, The Affiliated Nanhua Hospital, Hengyang Medical School; \\ ${ }^{2}$ Key Laboratory of Cancer Cellular and Molecular Pathology, Cancer Research Institute of \\ Hengyang Medical College, University of South China, Hengyang, Hunan 421001, P.R. China
}

Received August 17, 2021; Accepted November 17, 2021

DOI: $10.3892 / \mathrm{mmr} .2021 .12560$

\begin{abstract}
The $\kappa$-opioid receptor (KOR) is one of the primary receptors of opioids and serves a vital role in the regulation of pain, anesthesia, addiction and other pathological and physiological processes. KOR is associated with several types of cancer and may influence cancer progression. It has been proposed that KOR may represent a new tumor molecular marker and provide a novel basis for molecular targeted therapies for cancer. However, the association between KOR and cancer remains to be explored comprehensively. The present review introduces KOR and its association with different types of cancer. Improved understanding of KOR may facilitate development of novel antitumor therapies.
\end{abstract}

\section{Contents}

1. Introduction

2. Discovery, structure and typing of KOR

3. Expression and physiological function of KOR

4. Expression, function and significance of KOR in various types of cancer

5. Potential roles of KOR in cancer

6. Effects of opioids on tumors

7. Conclusion and future prospects

\section{Introduction}

Cancer represents a significant threat to human health worldwide and its burden of morbidity and mortality continues to rise. According to 2020 estimates from the World Health Organization, cancer is the first or second leading cause of premature death (death between the ages of 30 and 69 years)

Correspondence to: Professor Baiyun Wang, Department of Anesthesiology, The Affiliated Nanhua Hospital, Hengyang Medical School, University of South China, 336 Dongfeng South Road, Hengyang, Hunan 421001, P.R. China

E-mail:2549732620@qq.com

Key words: $\kappa$-opioid receptor, opioid, cancer, tumor in 91 out of 172 countries, and the third or fourth leading cause in another 22 countries (1).

Opioids serve a role in controlling the sensation of pain in the central and peripheral nervous systems; they also regulate cellular and humoral immune responses, as well as the expression of chemokines and chemokine receptors (2). Thus, the clinical application of opioids is extensive and includes perioperative analgesia and sedation, as well as pain reduction for patients with cancers (3), including pancreatic cancer (4), lung cancer (5), colorectal cancer (6), breast cancer (7) and head and neck cancer (8). Several experimental studies have shown that opioids promote proliferation, migration, invasion and angiogenesis in cancer cell culture and in vivo animal cancer models, such as morphine in the regulation of colorectal cancer cells (9) and human clear cell renal cell carcinoma cells (10), meanwhile morphine stimulates angiogenesis in mouse breast cancer models (11), which suggests that they may be harmful to patients with cancer. Preclinical studies have shown that opioids may be associated with cancer progression and recurrence, increased risk of infection and decreased overall survival $(12,13)$. However, other studies have found the opposite effect, namely that opioids may exhibit an inhibitory effect on a range of cancer cells and that use of opioids in in vivo animal cancer models does not promote tumor growth. For example, fentanyl inhibits the cell viability and invasion of lung (14), gastric (15) and colorectal (16) cancer. A study in which melanoma cells were injected into mice led to hyperalgesia at the injection site. Treatment with morphine can reduce local tumor growth and lung metastasis (17).

To date, an increasing number of studies (18) have shown that opioids and opioid receptors and peptides are widely distributed in various types of tumor cell and their expression levels differ depending on the tumor tissue type, such as breast cancer (19), colon cancer (20), endometrial cancer (21) and lung cancer (22). The upregulation of $\mu$-opioid receptor (MOR) in lung cancer samples with metastasis was found to be significantly higher than that in lung cancer samples without metastasis (23). MOR overexpression in human bronchoalveolar lung carcinoma cells led to increased tumor growth and lung metastases in nude mice compared with vector transfected cells (24). In addition, the stimulatory or inhibitory effects of opioids differ in different tumor cell types and are associated with growth, metastasis and prognosis of cancer. As MOR agonists, such as morphine and fentanyl, are the leading analgesics in clinical treatment of moderate and severe pain (25), 
MOR has greater clinical relevance than the $\kappa$-opioid receptor (KOR) and a relatively high number of studies on the association between MOR and cancer have been published (26-28). However, such opioids can cause side effects, such as euphoria, tolerance and respiratory depression, and have a high risk of addiction, drug abuse and death $(29,30)$.

Exogenous and endogenous opioid peptides regulate multiple functions of the body via ORs, such as food intake and weight control (31), response to pain (32), and regulation of cardiac function and the immune system $(33,34)$. KOR is one of the primary targets of opioids, with a potent analgesic effect and few side effects compared with MOR (35). KOR is a member of the G-protein-coupled receptor family and its natural endogenous ligand is dynorphin, which decreases synaptic transmission by inhibiting adenylate cyclase and voltage-gated calcium channels and activating voltage-gated potassium channels, resulting in decreased neuronal action potential production and neurotransmitter release (36). KOR was first cloned in 1993 (37) and is detectable in different tissues in rats, mice, guinea pigs, cattle and other animals. The understanding of ORs is increasing. KOR can be divided into different subtypes $(38,39)$. KOR is distributed in the brain, spinal cord and pain-sensing nerves $(40,41)$, thus it is most widely used in clinical analgesia during the perioperative period, such as using drugs that target KOR (e.g., oxycodone) $(42,43)$. Moreover, KOR is also expressed in the heart, lung, colon, liver and other organs, and is associated with the regulation of organ development, respiration, emotions, and motor, cardiovascular, neuroendocrine and cognitive function (44-48).

The structure and distribution of KOR provide an important basis for its participation in regulating various pathophysiological functions of the body $(49,50)$. Current evidence suggests that KOR serves a key role in the progression of tumors $(51,52)$. For example, clinical drugs targeting KOR, such as oxycodone and butorphanol, are given to patients with cancer to help eliminate or minimize the harmful effects of pain and stress on cancer progression (53). As commonly known, psychological states can affect the outcome of human disease, for example pain has a profoundly negative impact on the mood, social activities, day to day life, sleep and cognitive function of patients with cancer, which can even cause negative emotions such as stress and depression in caregivers too (54). Stress can promote tumor progression by inhibition of the expression of class-I and class-II major histocompatibility complex molecules and by reducing natural killer (NK) cell activity (55). KOR agonists acting on peripheral and spinal sites block tumor-induced bone pain (56). In addition, KOR is primarily expressed in the cell membrane, cytoplasm and nucleus. The expression levels of KOR in different subcellular locations may predict the prognosis of patients with tumors (57). In vitro experiments have demonstrated that KOR has different effects on different cancer cell types. For example, KOR inhibits proliferation and promotes apoptosis of nasopharyngeal carcinoma cells (58), and its overexpression may promote activation and invasion of breast cancer cells; these effects all involve activation of downstream signaling pathways (59).

Previous studies have shown that KOR is upregulated in various types of solid tumor, such as liver and non-small cell lung cancer and other malignant tumors, and KOR expression is associated with cancer growth and poor prognosis $(60,61)$. However, additional experiments are required to confirm the specific underlying mechanism. These observations confirm that KOR serves an important role in cancer development, including potentially promoting or inhibiting growth and metastasis of tumors and affecting patient prognosis.

Furthermore, inflammation promotes carcinogenic mutations that trigger changes in cytokine levels, stimulate angiogenesis and promote tumor immune evasion $(2,53)$. KOR expression has also been detected in immune cells, such as myeloid and $\mathrm{CD} 4^{+}$and $\mathrm{CD} 8^{+} \mathrm{T}$ cells $(2,62)$. Moreover, $\mathrm{KOR}$ mediates immunosuppressive effects, including decreased antibody production and inhibition of cytokine and chemokine expression (2).

\section{Discovery, structure and typing of KOR}

The existence of ORs was discovered in mammalian brain tissue using radioactive ligand binding in 1973 (63). To date, five opioid receptors have been identified: MOR, KOR, $\delta$ - and $\zeta$-OR and nociception receptor $(36,64)$. Numerous researchers have investigated the structure, typing, localization and function of ORs, which has provided novels routes for opioid drug research and development and laid a foundation for drug development and use $(65,66)$. KOR was first cloned from mouse brain in 1993 by Minami et al (37). The KOR endogenous ligand, dynorphin, was later identified as a 17-amino acid peptide derived from prodynorphin that is distributed in the central nervous system (67). However, they bind to ORs on the cell membrane, thereby regulating neuronal excitation via intracellular signaling pathways, which affect learning, cognition, nociception and endocrine function (68). Exogenous opioid peptides, such as morphine, heroin and fentanyl, also act by binding to ORs (69).

KOR belongs to the $\mathrm{G}$ protein-coupled receptor family of proteins, which share the same basic structure: An extracellular $\mathrm{N}$-terminal region, seven transmembrane domains and intracellular C-terminal and caudal regions (70). Hydrophobicity analysis has shown that the structure of KOR consists of three intracellular and three cytoplasmic rings, two extracellular glycosylation sites at the N-terminus and one intracellular phosphorylation site at the $\mathrm{C}$-terminus containing a disulfide bond $(45,46)$. Genetic analysis has suggested that OR genes are located on different human chromosomes $(45,71)$. As their exon/intron sequence is similar, it was originally hypothesized that the MOR, DOR and KOR may be derived from the same ancestral gene (72). However, different ORs have different pharmacological properties and are expressed in different anatomical locations (70). Terenius (69) isolated the full-length cDNA encoding human KOR using cDNA cloning technology. The KOR gene is located at q11-12 of human chromosome 8, with a coding region length of $\sim 1,143$ bases, translating into a protein of 380 amino acid residues. In addition, KOR mRNA transcripts are detectable in different tissues in rats, mice, guinea pigs and other animals, and have high homology with the sequence of the human KOR gene. This indicates that KOR gene sequences are highly conserved between different species $(37,73)$. However, the role of KOR splice variants at different sites is not fully understood. 


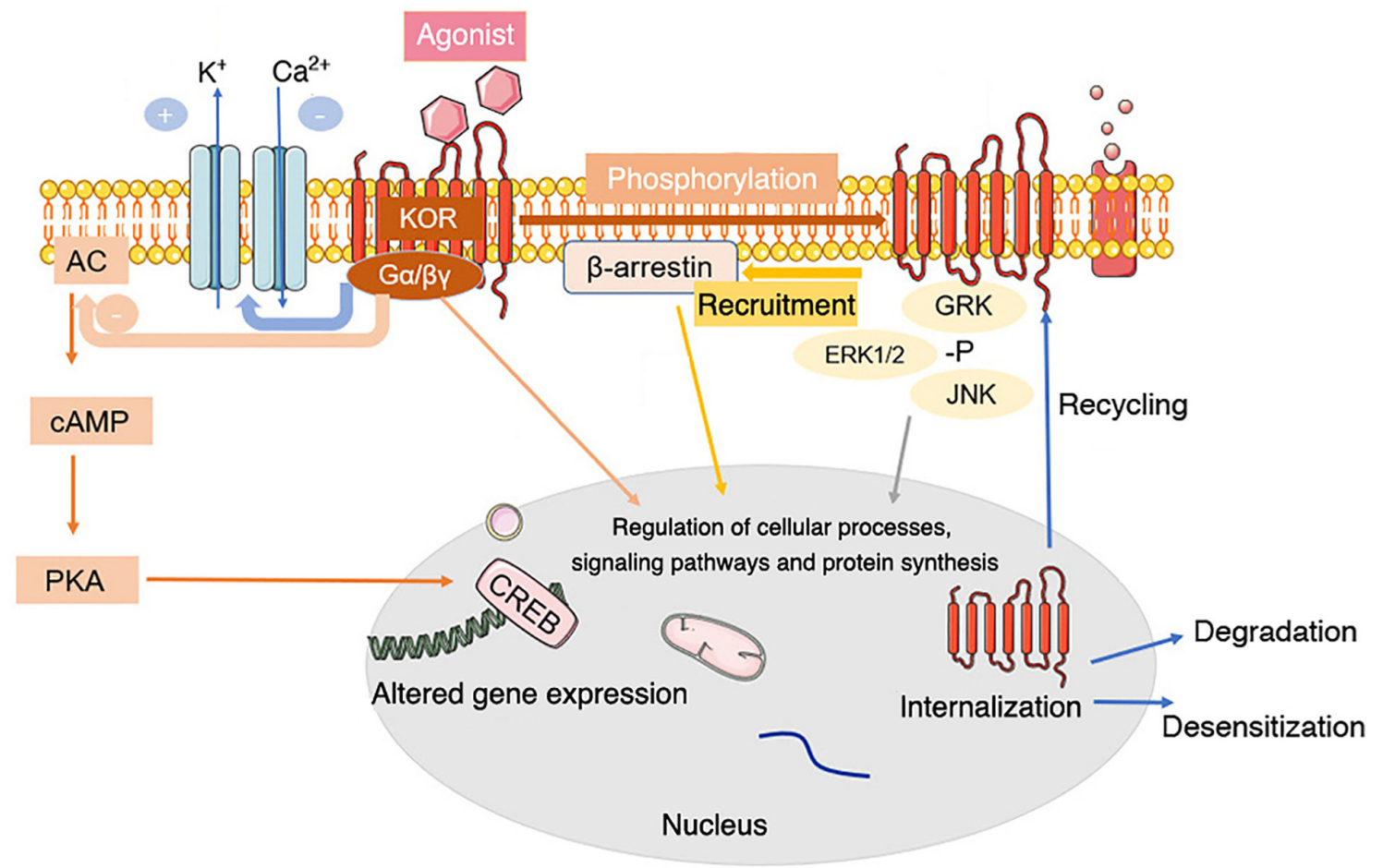

Figure 1. Common signal transduction and regulation of KOR. Activation of KOR leads to conformational changes and dissociation of the pertussis toxin-sensitive G-protein subunits, activating G-protein-gated inwardly rectifying potassium channels and inhibiting voltage-gated calcium ion channels. The $\alpha$ subunit binds GTP and dissociates from G $\beta \gamma$. The GTP-binding protein $\alpha$ subunit inhibits the classical adenylyl cyclase/cyclic AMP/PKA pathway. Both G $\alpha$-GTP and free G $\beta \gamma$ can regulate secondary cascade activation. KOR activation also activates a $\beta$-arrestin-dependent signaling cascade. This interaction with scaffolding partners, such as $\beta$-arrestin, can be dependent or independent of receptor phosphorylation. KOR is phosphorylated in response to agonist occupation by multiple kinases, each of which has multiple isoforms. Phosphorylation by a particular kinase dictates secondary cascade interactions or subsequent receptor fate. Phosphorylation of KOR leads to internalization of the receptor, contributing to KOR agonist tolerance, response to agonist occupancy and subsequent signaling pathway activation, desensitization or degradation of the receptor. +, activation; -, blockade or inhibition; KOR, $\mathrm{k}$-opioid receptor; AC, adenylyl cyclase; cAMP, cyclic AMP; CREB, cAMP responsive element binding protein; PKA, protein kinase A; G $\alpha / \beta \gamma, \mathrm{G}$ protein $\alpha / \beta \gamma$ subunit; GRK, G protein-coupled receptor kinase 1 ; -P, pyrophosphate.

Receptor-ligand binding and competitive inhibition experiments have demonstrated that KOR has two different binding sites $(74,75)$. Accordingly, KOR is divided into two different subtypes. The $\kappa 1$ subtype is sensitive to [D-Ala ${ }^{2}$, D-Leu ${ }^{5}$-enkephalin (DADLE), but not to U50488H, whereas the $\kappa 2$ subtype is sensitive to U50488H, but not to DADLE. $\kappa_{1}$ ORs can also be divided into $\kappa 1_{\mathrm{A}}$ and $\kappa 1_{\mathrm{B}}$ sub-subtypes. Similarly, $\kappa 2$-subtype ORs can be divided into $\kappa 2_{\mathrm{A}}$ and $\kappa 2_{\mathrm{B}}$ sub-subtypes. In addition, a third subtype, subtype $\kappa 3$, has also been proposed. The receptor-binding characteristics of the $\kappa 3$ - and $\kappa 2$-subtype opioid receptors are similar $(38,39)$. Thus, KOR is still largely divided into only two subtypes, $\kappa 1$ and $\kappa 2$. Since most of the aforementioned KOR types are based on radioligand receptor binding experiments, further studies are needed to confirm their classification. Given the heterogeneity of the effects of KOR, additional preclinical studies are needed to gain insight into the specific mechanisms of action.

\section{Expression and physiological function of KOR}

KOR was originally considered to be expressed exclusively in the central nervous system (37). In situ hybridization experiments in rats revealed that KOR mRNA is present in the dentate gyrus of the hippocampus, hypothalamus, certain thalamic nuclei, descending conduction pathway of the cerebral cortex, caudate nucleus, olfactory bulb, nucleus accumbens, brainstem, spinal cord and other parts (46). Previous studies have observed KOR mRNA expression in the heart, kidney, adrenal medulla, digestive tract, peripheral vascular, uterus, placenta, T cells and macrophages of humans and animals. Nevertheless, the density of KOR in central nervous tissue is higher than that in peripheral tissue (44-48). This suggests that KOR is widely distributed, which provides a basis for its potential involvement in regulating various physiological functions of the body.

KOR can bind to the heterotrimer G proteins Gi and Go, which are sensitive to pertussis toxin (72). When opioid peptides or specific receptor agonists bind to KOR on the cell membrane, KOR activation leads to the dissociation of $\mathrm{G}$ proteins into $\mathrm{G} \alpha$ and $\mathrm{G} \beta \gamma$ subunits, which mediate various intracellular signaling pathways (76,77) (Fig. 1).

KOR also interact with various helper proteins and alter the effectiveness of agonist-mediated cell signaling pathways, such as activating the extracellular signal-regulated kinase (ERK1/2) (78), c-Jun amino-terminal kinase (79), JAK2/STAT3 and interferon regulatory factor 2 signaling (80), which determine the signals produced and influence receptor transport, targeting, fine-tuning and intracellular localization by providing scaffolds that connect receptors and cytoskeletal networks $(77,81)$.

Pain is a common initial signal for a patient to seek medical attention and $30-50 \%$ of patients with cancer experience moderate to severe pain that has a notable negative 
Table I. Regulation of KOR in various types of cancer.

\begin{tabular}{|c|c|c|c|c|}
\hline Type of cancer & Regulation of KOR & Function & Prognosis & (Refs.) \\
\hline Hepatocellular carcinoma & Downregulated & $\begin{array}{l}\text { Promotes growth, invasion and angiogenesis; } \\
\text { inhibits differentiation }\end{array}$ & Poor & $(60)$ \\
\hline $\begin{array}{l}\text { Esophageal squamous } \\
\text { cell carcinoma }\end{array}$ & Upregulated & Promotes metastasis and growth & Poor & $(57)$ \\
\hline Non-small cell lung & Upregulated & $\begin{array}{l}\text { Promotes chemosensitivity; inhibits proliferation } \\
\text { and growth }\end{array}$ & Good & (108) \\
\hline Breast & Upregulated & $\begin{array}{l}\text { Promotes chemosensitivity; inhibits growth and } \\
\text { proliferation }\end{array}$ & Good & $(117-119)$ \\
\hline Prostate & Upregulated & Inhibits proliferation & Unknown & $(126,127)$ \\
\hline Kidney & Upregulated & Promotes proliferation & Unknown & (10) \\
\hline Nasopharyngeal carcinoma & Upregulated & Promotes apoptosis & Unknown & $(58)$ \\
\hline Glioma & Upregulated & Promotes proliferation and DNA synthesis & Unknown & $(132)$ \\
\hline
\end{tabular}

KOR, $\kappa$-opioid receptor.

impact on their quality of life (82). Opioids are often used to relieve cancer-associated pain in patients and improve quality of life $(83,84)$. KOR has long been a research target for novel analgesics because activating KOR relieves pain effectively without causing side effects such as addiction, respiratory depression and constipation (85).

Moreover, KOR is essential for emotional regulation. Studies have shown that the endogenous opioid peptide dynorphin activates KOR in the nucleus accumbens and KOR agonists inhibit dopamine (DA) transmission (86). By contrast, KOR antagonists increase the release of basal DA and may produce antidepressant-like effects (35). The role of KOR in behavioral despair, stress and other depression models has been studied and activation of KOR can regulate anxiety-like behavior (87-89). Buprenorphine is a KOR antagonist and a MOR partial agonist. In animal models, buprenorphine significantly decreased forced swimming immobility time (90) and clinical trials have shown potential for the treatment of depression in patients who do not respond to traditional antidepressants $(91,92)$. It has been reported that the KOR and MOR agonist (-)-3-N-Ethylaminothiazolo [5,4-b]-N-cyclopropylmethylmorphinan hydrochloride serves an antidepressant and anti-anxiety role (93), however, the underlying mechanism remains to be explored.

KOR activation also stimulates hippocampal cholinergic neurons, thus alleviating scopolamine-induced memory impairment and decreasing cognitive impairment caused by ischemic hippocampal nerve injury $(94,95)$. Moreover, activation of KOR decreases brain tissue damage, improves brain function and promotes brain function recovery in numerous animal models of cerebral ischemia $(96,97)$.

A variety of ORs are found in the heart, among which KOR is dominant. The heart secretes endogenous or paracrine opioid peptides and regulates cardiac function by acting on ORs on the myocardium; this serves a critical role in fighting oxidative stress and myocardial ischemia/reperfusion injury $(44,98)$. The myocardial protective effects of selective KOR agonist U50488H and butorphanol tartrate, which primarily acts on KOR-based analgesic agents, have been demonstrated (99-101).
Lastly, KOR agonists can be used for the treatment of refractory pruritus. Nalfurafine (TRK-820), a highly selective KOR agonist is used to treat pruritus in patients with uremia and chronic pain liver disease and those receiving peritoneal dialysis (102). In addition, KOR is also involved in regulating respiration, immunity, exercise, addiction, feeding, diuresis and other functions (103).

\section{Expression, function and significance of $\mathrm{KOR}$ in various types of cancer}

Hepatocellular carcinoma (HCC). Liver cancer is predicted to be the sixth most commonly diagnosed cancer and the fourth leading cause of cancer death worldwide in 2018, accounting for $\sim 841,000$ new cases and 782,000 deaths annually (104). $\mathrm{HCC}$ is the most common subtype of liver cancer, accounting for $75-85 \%$ of primary liver cancer (104). The main risk factors for HCC include chronic infection with hepatitis B virus or hepatitis $\mathrm{C}$ virus, aflatoxin-contaminated food, heavy alcohol intake and type 2 diabetes (105).

Chen et al (60) used reverse transcription (RT) fluorescence quantitative (q)PCR to detect the expression of KOR mRNA in liver cancer and adjacent tissue samples and found that the expression of KOR mRNA in liver cancer tissue was significantly lower than that in adjacent tissue samples (Table I). Subsequent immunohistochemical detection of 174 cases of liver cancer showed that the expression of KOR protein in liver cancer tissue was significantly downregulated (60). Further analysis showed that low expression of KOR at both the mRNA and protein levels was significantly associated with invasive clinicopathological features (such as tumor size, vascular invasion, differentiation and TNM stage) of patients with HCC. Moreover, Kaplan-Meier survival analysis suggested that downregulation of KOR in HCC predicted a poor prognosis for patients with HCC (60). Patients with decreased KOR expression had a lower survival rate and increased recurrence (60). Therefore, KOR may inhibit the progression of HCC and could represent a potential therapeutic target for the treatment of 
HCC. These results indicate that down-regulation of KOR in $\mathrm{HCC}$ tumor tissues has a strong association with poor prognosis and KOR might be a potential tumor suppressor. However, the localization of $\mathrm{KOR}$ in $\mathrm{HCC}$ cells remain unclear, and the association between KOR and HCC remains to be fully elucidated. Future studies should examine the role of KOR in the occurrence and development of HCC and other types of liver cancer, as well as the underlying regulatory mechanisms.

Non-small cell lung cancer (NSCLC). At present, the incidence and mortality of lung cancer rank among the highest across all cancer types globally, and most cases are NSCLC (106). A research analysis (61) indicated that opioid receptors are more highly expressed in various human solid cancers, and KOR expression was found to be increased at the mRNA level in adenocarcinomas of the lung and pancreas, prostate carcinoma and myxoid/round cell liposarcoma, compared with healthy control tissues (Table I).

As early as 1990, KOR agonists were shown to inhibit the proliferation of H157 NSCLC cells (107). A follow-up study (108) has reported that KOR is highly expressed in two NSCLC cell lines (HCC827 and H1975) and treating these cells with the selective KOR agonist U50488H decreases their viability and proliferation in a concentration-dependent manner and the selective KOR antagonist norbinaltorphimine reverses this effect. Gefitinib is an oral epidermal growth factor receptor-tyrosine kinase (EGFR-TK) inhibitor (109). Inhibition of EGFR-TK inhibits tumor growth, metastasis and angiogenesis, and increases cancer cell apoptosis $(110,111)$.

The inhibition of tumor cell viability and proliferation by gefitinib in HCC827 cells can be further enhanced by co-treatment with the selective KOR agonist U50488H (108). Glycogen synthase kinase (GSK)3- $\beta$ is a multifunctional serine/threonine kinase involved in regulating the function of several metabolism and signaling pathways, as well as proteins and transcription factors (112). GSK3 $\beta$ drives oncogenic progression either by its inhibition or its activation, depending on the cell type. Inactivation of GSK3 $\beta$ has been reported in lung cancer (113) and higher level of inactivated of GSK $3 \beta$ (pSer9GSK3 $\beta$ ) observed (114). Phosphorylation of GSK3- $\beta$ leads to inactivation of the tumor suppressor gene p53, which is key to the progression of several types of cancer $(115,116)$. Following treatment with KOR agonist U50488H, phosphorylation of GSK-3 $\beta$ is decreased in H1975 lung cancer cells (108). Activation of KOR may decrease GSK-3 $\beta$ phosphorylation by inhibiting the $\mathrm{cAMP} /$ protein kinase A pathway or activating the JNK pathway, thus inhibiting NSCLC growth (108). These findings suggest that KOR may serve a role in the prevention and treatment of NSCLC and KOR may augment the effect of anti-tumor drugs, decreasing drug resistance and activating key signaling pathways and molecules to inhibit lung cancer cell proliferation and promote apoptosis (108).

Breast cancer. KOR is also expressed in primary breast cancer and different breast cancer cell lines, such as MCF7 and T47D $(117,118)$. It has been reported that opioids inhibit the growth of the human T47D breast cancer cell line via KOR in a dose-dependent manner (118). In a follow-up study, it was also found that the chemotherapeutic drug paclitaxel bound to KOR, which exhibited an anti-tumor effect in breast cancer, suggesting that KOR directly enhanced the effect of this drug and modulated cancer cell viability and proliferation (118). A retrospective analysis of triple-negative breast cancer found that intraoperative use of opioids was associated with decreased risk of tumor recurrence (119). KOR is upregulated and Toll-like receptor 4 is downregulated in breast tumor tissue compared with normal breast tissue (119). Kaplan-Meier survival analysis has suggested that low expression of KOR in patients with breast cancer is associated with shorter overall and disease-free survival (52). KOR is also upregulated in breast cancer compared with normal human mammary epithelial cells (59). In addition, downregulation of KOR inhibits survival and migration of breast cancer cells and decreases expression of proteins and genes associated with epithelial-to-mesenchymal transition, such as N-cadherin, Snail and vimentin, while increasing the expression of E-cadherin (59). KOR knockdown also promotes inactivation of the PI3K/AKT signaling pathway, which decreases cell viability and promotes cell death (59). KOR may be a potential tumor suppressor, which may be associated with epithelial-mesenchymal transformation and regulation of the PI3K/AKT signaling pathway (59). Altogether, these findings suggest that analgesics that target KOR activation may be suitable for patients with breast cancer.

Esophageal squamous cell carcinoma (ESCC). Esophageal cancer is the sixth leading cause of cancer-associated mortality in the world. According to statistics from the International Agency for Research on Cancer, $>80 \%$ of esophageal cancer cases are ESCC (120). The geographical distribution of ESCC is heterogeneous and China has a high incidence of ESCC (120), where it is the fourth most common malignancy.

Zhang et al (57) found that KOR is highly expressed in the KYSE180 and EC109 ESCC cell lines. Immunohistochemical staining results of patients with ESCC suggested that KOR was highly expressed in esophageal cancer tissue. In addition, KOR protein was highly expressed on the membrane of cancer cells and significantly upregulated in the nucleus and cytoplasm. Follow-up analysis of clinicopathological features of 256 patients with ESCC showed that high nuclear expression of KOR was significantly associated with lymph node metastasis. Therefore, overexpression of KOR in ESCC may have functional significance, and nuclear KOR expression may be a risk factor for lymph node metastasis. However, there is no clear evidence that KOR is as a tumor marker of ESCC.

Urological and prostate tumors. Previous retrospective studies have shown that patients undergoing prostate or bladder cancer surgery have higher disease-specific and disease-free survival, as well as increased tumor recurrence rates are likely to increase with increased perioperative opioid use $(12,121,122)$.

In 1988, dynorphin was shown topromote proliferation of the DU145 prostate cancer cell line by activating KOR. Naloxone, a classical OR antagonist, increased cell viability and proliferation by $25 \%$ when used alone but paradoxically inhibits the effects of dynorphin on cell viability and proliferation when the two drugs are used in combination (123). Kampa et al (124) demonstrated that KOR is expressed in the PC3 and DU145 androgen-independent prostate cancer cell lines. Subsequently, a novel opiate-active peptide (Tyr-Ile-Phe-Asn-Leu) was found to bind to KOR and exhibit an effective, dose-dependent and 
reversible anti-proliferation effect on PC3 and DU145 prostate cancer cells (125). Yamashita et al (126) detected KOR mRNA expression in the $\mathrm{LNCaP}$ and $\mathrm{VCaP}$ cell lines using RT-qPCR analysis. Androgens may affect the proliferation and viability of prostate cancer cells partly by regulating OR expression and other mechanisms $(126,127)$.

The selective KOR opioid agonist U50488 induces proliferation of 768-O and RLC-310 renal carcinoma cells; this may be mediated by the anti-apoptotic protein surviving (10).

The aforementioned individual reports revealed the association between KOR, androgens and anti-apoptotic proteins and may have important implications for understanding urological tumor formation and treatment. To the best of our knowledge, however, studies on the association between KOR and tumors of the urinary system are still scarce, and further studies are needed to confirm the aforementioned preliminary findings.

Glioma. Glioma is the most common tumor of the central nervous system, accounting for $80 \%$ of malignant brain tumors (128). The rat C6 glioma cell line has been used as a model to study various mechanisms of opioid action (129-131). Using RT-PCR analysis and radioligand studies, it has been demonstrated that C6 cells express KOR $(129,130)$. Bohn et al (132) found that the KOR selective agonist U-69,593 stimulates proliferation of $\mathrm{C} 6$ cells by activating phospholipase C (PLC), PKC and ERK (132). In this regard, the function of KOR seems to be the opposite of that of MOR; activation of MOR in C6 glioma cells attenuates KOR-induced DNA synthesis and tumor proliferation, suggesting that MOR may be a negative regulator of KOR in glioma (133).

Other types of cancer. Pheochromocytoma results in production of opioid peptides, such as dynorphins (134). The KOR binding site is the most common opioid binding site in surgically resected pheochromocytoma and the Kat 45 human pheochromocytoma cell line (134). Activation of KOR inhibits biosynthesis and release of catecholamine in pheochromocytoma (134). In addition, the expression of KOR may be associated with paracrine regulation of the proliferation of pheochromocytoma cells $(134,135)$. The KOR agonist U-69,593 inhibits the expression of EGF on pheochromocytoma cells in PC12 rats (136). However, the upregulation of the KOR ligand in human pheochromocytoma compared with normal tissue has not been demonstrated to be statistically significant, and it is unclear whether KOR agonists activate other molecules and downstream signaling pathways via KOR.

In the endometrium, KOR is the most common opioid binding site (21), and its endogenous ligand dynorphin is produced in also this tissue (137). TGF $\beta 1$ is a primary endometrial growth factor that affects proliferation of normal and tumor human endometrial epithelial and stromal cells and promotes apoptosis of normal endometrial stromal cells $(138,139)$. Chatzaki et al $(137)$ found that treatment with U-69,593, a specific KOR activator, inhibits production of TGF $\beta 1$ in normal, epithelial, stromal and Ishikawa endometrial cancer cells.

It has been reported that the presence of KOR in the CNE-2 human nasopharyngeal carcinoma cell line promotes tumor cell apoptosis by activating the PLC pathway (58).
KOR is located in the excitatory and inhibitory motor neurons of the intermuscular nerve of the gastrointestinal tract and human colon (140). KOR inhibits excitatory transmission of the neuromuscular and attenuates gastrointestinal peristalsis (140). The expression of KOR is increased in primary gastric and duodenal neuroendocrine tumors compared with paracancerous tissue. In a prospective study, KOR expression was associated with distant liver metastasis of small intestinal and pancreatic neuroendocrine tumors (141). These results all suggest that KOR serves an essential role in cancer.

\section{Potential roles of KOR in cancer}

Angiogenesis. Tumor angiogenesis is necessary for tumor progression, the provision of nutrients and oxygen, as well as the removal of metabolic waste and carbon dioxide (142). Neovascularization in tumor tissue is a complex process of imbalance between pro- and antiangiogenic factors in the tumor microenvironment (142). Anti-angiogenesis therapy has achieved promising results in gastric and colorectal cancer, as well as NSCLC and other types of malignant tumor $(143,144)$. Vascular growth factors such as vascular endothelial growth factor (VEGF) are highly expressed in tumors and induce tumor angiogenesis $(142,145)$. In the clinic, angiogenesis inhibitors targeting VEGF signaling are used as anticancer drugs (146), such as Avastin (bevacizumab) is a monoclonal antibody against VEGF in ovarian (147), colorectal (148), kidney (149) and breast $(150)$ cancer. Studies by Yamamizu et al $(51,151,152)$ have suggested that activation of KOR inhibits differentiation and tissue angiogenesis of embryonic stem cell-derived Flk1 ${ }^{+}$ vascular endothelial progenitor cells. KOR agonists U50488H and TRK820 inhibit vascular endothelial cell migration and angiogenesis by inhibiting VEGF receptor expression, although continued use of higher doses of TRK820 have no significant effect on tumor growth. In addition, Lewis lung cancer (LLC) or B16 melanoma has been transplanted subcutaneously into KOR knockout mice. At 19 days post-transplantation, LLC and B16 tumors in KOR knockout mice were significantly larger in size and weight than those in control mice and showed greater proliferation and tumor angiogenesis. These results suggest that KOR activation inhibits tumor angiogenesis $(51,151,152)$. Although a number of individual angiogenesis inhibitors have demonstrated their ability to inhibit tumor progression and metastasis in a variety of cancer models, the effects of tumor regression vary by cancer type when the same angiogenesis inhibitors are used, suggesting that the future direction of anti-angiogenesis gene therapy is to identify prognostic biomarkers to help determine the most effective angiogenesis inhibitor genes for each cancer, which will largely depend on further understanding of the biological mechanisms of tumor angiogenesis. In view of the anti-angiogenic effects of KOR, the possibility of developing novel targeted drugs in combination with chemotherapy, targeted therapy and immunomodulatory drugs in the treatment of various types of cancer should be explored (Fig. 2).

Inflammation. Inflammation is usually associated with the development and progression of cancer (153). The cells that cause cancer-related inflammation are genetically stable, so drug resistance does not appear quickly; therefore, targeting 


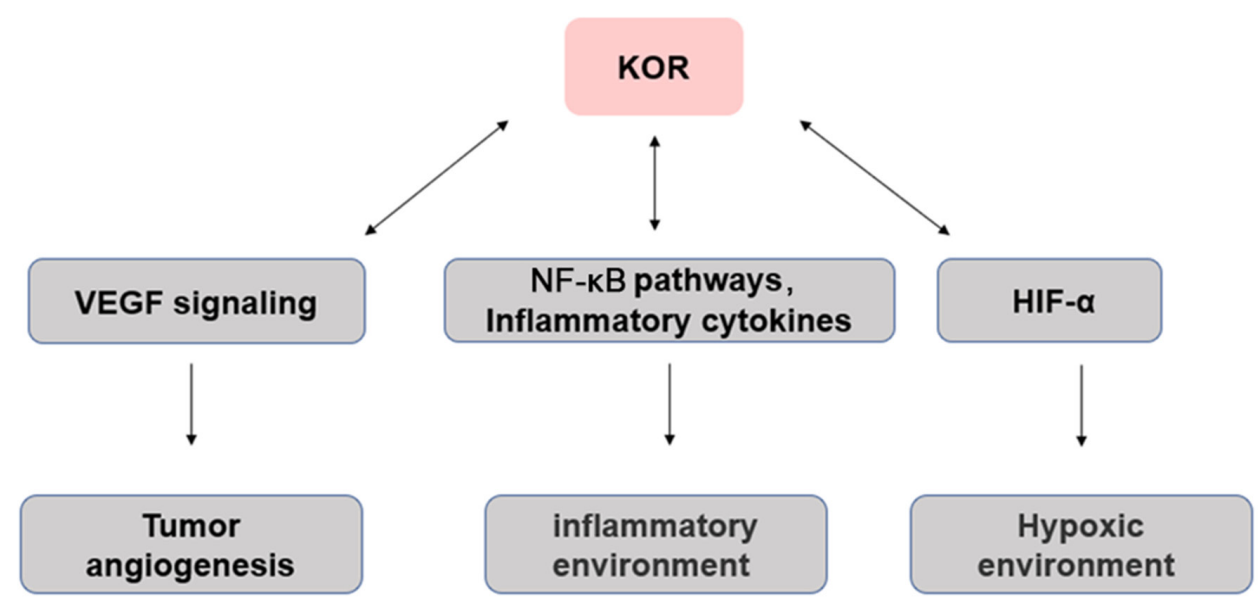

Figure 2. Interaction between KOR and the tumor microenvironment. Arrows indicate regulation. KOR, $\kappa$-opioid receptor; HIF-1 $\alpha$, hypoxia-inducible factor $\alpha$; VEGF, vascular endothelial growth factor.

inflammation is an attractive strategy for cancer prevention and treatment (153). Inflammation promotes the occurrence and development of certain types of tumor, but inhibits others, including bacterial and viral infections, autoimmune diseases, obesity, smoking, asbestos exposure and excessive alcohol consumption, all of which increase the risk of cancer and stimulate malignant progression $(153,154)$. In addition, chronic inflammation promotes carcinogenic mutations, as well as changes in pro-inflammatory cytokines that stimulate angiogenesis and promote tumor immune evasion $(2,53)$.

Previous studies $(48,62,155)$ have shown that ORs are distributed outside the central nervous system, such as on the surface of various types of immune cell, including monocytes, macrophages and neutrophils, as well as T and B lymphocytes.

ORs serve an essential role in immune regulation, which can lead to neuroinflammation of the central nervous system and immune suppression of the peripheral immune system $(48,62)$. There is evidence that KOR-specific activators exert different anti-inflammatory effects. For example, KOR-specific activators inhibit phagocytosis of macrophages, aggregation of neutrophils, release of TNF- $\alpha$, IL-10, IL-1 and IL-6, production of inducible nitric oxide synthase, nitric oxide release and nuclear translocation of NF- $\mathrm{NB} / \mathrm{p} 65$ induced by lipopolysaccharide $(156,157)$. Morphine affects the inflammatory response in the tumor microenvironment (158). Immunosuppression has been reported as the downregulation of NK cell activity, responses of T and B cells to mitogens, antibody formation in vivo and in vitro, reduction of phagocytic and microbicidal activity of neutrophils and macrophages $(154,158)$, cytokine and chemokine production by macrophages (159), microglia and astrocytes, sensitization to various infections using animal models, and the enhanced replication of human immunodeficiency virus in vitro (158). Moreover, MOR and KOR may have opposite effects, with the former associated with induction of pro-inflammatory activity and the latter with anti-inflammatory activity (159). Therefore, KOR may indirectly affect the occurrence and development of tumors via its effects on inflammation (Fig. 2).

Hypoxia. Hypoxia serves an important role in the tumor microenvironment. In solid tumors, cancerous cells adapt to a hypoxic environment through a variety of cellular mechanisms (160). Hypoxic tumor cells secrete VEGF and lactate, as well as a number of cytokines that modulate the tumor microenvironment, which increases their viability $(160,161)$. The expression levels of KOR and hypoxia-inducible factor $1 \alpha(\mathrm{HIF}-1 \alpha)$ are significantly increased in live human neurons following 24-h hypoxia (162). HIF-1 $\alpha$ knockdown decreases KOR expression (162). Thus, during hypoxia, KOR promotes cell viability and its expression may be regulated by HIF-1 $\alpha$ (163). In addition, the induction of hypoxia in neuroblastoma cells leads to KOR internalization, which is inhibited by selective KOR antagonists or dynein inhibitors and reversed by reoxygenation (162). Thus, regulation of KOR during hypoxia is mediated by its activation via a dynein-dependent mechanism Further investigations are required to determine whether the mechanism underlying the association between hypoxia influences cancer onset (Fig. 2).

\section{Effects of opioids on tumors}

Archaeologists speculate that as early as the Neolithic period, human ancestors found poppies in the mountains of the Mediterranean (164). Following the invention of the hypodermic syringe and hollow needle in the 1850s, morphine began to be used in minor surgery, both for postoperative and chronic pain and as an adjunct to general anesthetic (164).

The World Health Organization-based three-step medication principle (165) has been used to treat cancer-associated pain. Pain potentially decreases survival (166), one primary mechanism for the potential effects of opioids on survival is through immune effects (167), so it remains vital that pain is effectively managed. Adequate control of cancer-associated pain using opioids has been shown to improve quality of life, compliance with cancer treatment and decrease emotional stress, and thus may have a positive impact on patient survival $(168,169)$. Cancer treatment primarily includes surgical resection $(170,171)$, postoperative radiotherapy (172), chemotherapy and targeted therapy $(173,174)$, although certain patients experience recurrence and metastasis following treatment. However, several studies have shown that periand postoperative opioid analgesics affect the metastasis 
and recurrence of cancer, although the reported effects are inconsistent (175-177).

Clinical drugs targeting KOR, such as oxycodone (178) and butorphanol (179), are KOR/MOR mixed agonists. Similar to morphine, oxycodone inhibits proliferation and migration of human lung adenocarcinoma cells and induces apoptosis (180). In addition, oxycodone has different effects on the proliferation, migration and apoptosis of cancer cells and weakens or enhances the efficacy of chemotherapy, depending on the type of cancer cells and the expression levels of EGFR in these cells (181).

Transmembrane protein with EGF-like and two follistatin like domains 1 (TMEFF1) serves a vital role in the development of various types of tumor, including brain (182), endometrial carcinoma (183) and ovarian cancer (184). Butorphanol significantly inhibits the malignant biological behavior of ES-2 and SKOV3 ovarian cancer cells and the expression of TMEFF1 is significantly downregulated in ovarian cancer cells (185).

\section{Conclusion and future prospects}

Opioids are often considered to have a negative impact on cancer prognosis (169), the effects of opioid receptors observed in patients with cancer are different, so the relationship between opioid receptors and cancer has attracted attention (186). Several studies have shown that targeting KOR may be applied to treat a variety of diseases $(87-89,94,95,187)$. Despite the availability of several types of treatment, cancer remains a significant threat to human health (188). The opioid system is associated with cancer progression and cell proliferation and tumor prognosis $(51,53)$. ORs affect patients with cancer differently $(23,27,51)$; therefore the association between ORs and cancer is important. In recent years, KOR has been found to be associated with several types of cancer and may influence its progression and prognosis $(52,127,189)$. In addition to its impact on analgesia and the immune, endocrine, nervous and cardiovascular systems (103), KOR also has a significant impact on certain types of solid tumors and cancer cells and may affect the prognosis of patients with cancer $(57,59,60)$. Most OR agonists bind to KOR and inhibit cell proliferation (124). Thus, KOR may be a potential therapeutic target for cancer therapy. This may facilitate the development of novel drugs and a strategic shift in the treatment of intra- and postoperative, as well as cancer-associated, pain.

Nevertheless, the notion that KOR can be a potential therapeutic target needs further research. At present, preliminary basic studies on the effect of KOR on tumors are not comprehensive, and most are in vitro experiments $(10,58,59)$. Most of the available clinical studies are retrospective in design and the conclusions are not consistent $(52,186)$. Therefore, when treating patients with cancer, the dosage and treatment duration of opioids should be weighed $(186,190)$. To design opioid analgesics without side effects, it is important to understand the molecular mechanisms, signaling pathways and effects of KOR in combination with chemotherapeutic drugs (191). For example, by decreasing entry of opioids into the central nervous system, selective targeting of KOR to the peripheral nervous system and inflammatory tissues is biased towards activation of analgesia-associated intracellular signaling pathways. Additionally, clinical trials are needed to test the efficacy of KOR in cancer therapy and to identify its potential benefits in decreasing cancer morbidity and mortality, as well as improving quality of life. Further investigation of the roles of KOR may facilitate development of novel treatment for cancer and other types of disease.

\section{Acknowledgements}

Not applicable.

\section{Funding}

The present study was supported by the Clinical Medical Technology Innovation Project of Hunan (grant nos. 2020SK51903 and 2018SK51702).

\section{Availability of data and materials}

Not applicable.

\section{Authors' contributions}

QZ and ZZ conceived the study. SL and WL performed the literature search. QZ drafted the manuscript. BW and NL critically revised the manuscript. Data authentication is not applicable. All authors have read and approved the final manuscript.

\section{Ethics approval and consent to participate}

Not applicable.

\section{Patient consent for publication}

Not applicable.

\section{Competing interests}

The authors declare that they have no competing interests.

\section{References}

1. Ferlay J, Colombet M, Soerjomataram I, Parkin DM, Piñeros M, Znaor A and Bray F: Cancer statistics for the year 2020: An overview. Int J Cancer: April 5, 2021 (Epub ahead of print).

2. Rogers TJ: Kappa opioid receptor expression and function in cells of the immune system. Handb Exp Pharmacol 271: 419-433, 2022.

3. Trescot AM: Review of the role of opioids in cancer pain. J Natl Compr Cancer Netw 8: 1087-1094, 2010.

4. Lohse I and Brothers SP: Pathogenesis and treatment of pancreatic cancer related pain. Anticancer Res 40: 1789-1796, 2020.

5. Mercadante S and Vitrano V: Pain in patients with lung cancer: Pathophysiology and treatment. Lung Cancer 68: 10-15, 2010.

6. Szczepaniak A, Fichna J and Zielińska M: Opioids in cancer development, progression and metastasis: Focus on colorectal cancer. Curr Treat Options Oncol 21: 6, 2020.

7. Satija A, Ahmed SM, Gupta R, Ahmed A, Rana SPS, Singh SP, Mishra S and Bhatnagar S: Breast cancer pain management-a review of current \& novel therapies. Indian J Med Res 139: 216-225, 2014.

8. Ing JW: Head and neck cancer pain. Otolaryngol Clin North Am 50: 793-806, 2017.

9. Lu H, Zhang H, Weng ML, Zhang J, Jiang N, Cata JP, Ma D, Chen WK and Miao CH: Morphine promotes tumorigenesis and cetuximab resistance via EGFR signaling activation in human colorectal cancer. J Cell Physiol 236: 4445-4454, 2021. 
10. Ma Y, Ren Z, Ma S, Yan W, He M, Wang D and Ding P: Morphine enhances renal cell carcinoma aggressiveness through promotes survivin level. Ren Fail 39: 258-264, 2017.

11. Ustun F, Durmus-Altun G, Altaner S, Tuncbilek N, Uzal C and Berkarda S: Evaluation of morphine effect on tumour angiogenesis in mouse breast tumour model, EATC. Med Oncol 28 : 1264-1272, 2011

12. Guerrero Orriach JL, Raigon Ponferrada A, Malo Manso A, Herrera Imbroda B, Escalona Belmonte JJ, Ramirez Aliaga M, Ramirez Fernandez A, Crespo JD, Soriano Perez AM, Fontaneda Heredia A, et al: Anesthesia in combination with propofol increases disease-free survival in bladder cancer patients who undergo radical tumor cystectomy as compared to inhalational anesthetics and opiate-based analgesia. Oncology 98 $161-167,2020$.

13. Hasegawa T, Oguri T, Osawa T, Sawa T, Osaga S, Okuyama T, Uchida M, Maeno K, Fukuda S, Nishie H, et al: Opioid dose and survival of patients with incurable nonsmall cell lung cancer: A prospective cohort study. J Palliat Med 21: 1436-1441, 2018.

14. Gong S, Ying L, Fan Y and Sun Z: Fentanyl inhibits lung cancer viability and invasion via upregulation of miR-331-3p and repression of HDAC5. Onco Targets Ther 13: 13131-13141, 2020.

15. Li C, Qin Y, Zhong Y, Qin Y, Wei Y, Li L and Xie Y: Fentanyl inhibits the progression of gastric cancer through the suppression of MMP-9 via the PI3K/Akt signaling pathway. Ann Transl Med 8: 118, 2020

16. Zhang XL, Chen ML and Zhou SL: Fentanyl inhibits proliferation and invasion of colorectal cancer via $\beta$-catenin. Int J Clin Exp Pathol 8: 227-235, 2015.

17. Sasamura T, Nakamura S, Iida Y, Fujii H, Murata J, Saiki I, Nojima $\mathrm{H}$ and Kuraishi Y: Morphine analgesia suppresses tumor growth and metastasis in a mouse model of cancer pain produced by orthotopic tumor inoculation. Eur J Pharmacol 441: 185-191, 2002.

18. Fichna $J$ and Janecka A: Opioid peptides in cancer. Cancer Metastasis Rev 23: 351-366, 2004.

19. Chatikhine VA, Chevrier A, Chauzy C, Duval C, d'Anjou J, Girard N and Delpech B: Expression of opioid peptides in cells and stroma of human breast cancer and adenofibromas. Cancer Lett 77: 51-56, 1994

20. Zagon IS, Hytrek SD and McLaughlin PJ: Opioid growth factor tonically inhibits human colon cancer cell proliferation in tissue culture. Am J Physiol 271: R511-R518, 1996.

21. Hatzoglou A, Gravanis A, Margioris AN, Zoumakis E and Castanas E: Identification and characterization of opioid-binding sites present in the Ishikawa human endometrial adenocarcinoma cell line. J Clin Endocrinol Metab 80: 418-423, 1995.

22. Roth KA and Barchas JD: Small cell carcinoma cell lines contain opioid peptides and receptors. Cancer 57: 769-773, 1986.

23. Singleton PA, Mirzapoiazova T, Hasina R, Salgia R and Moss J: Increased $\mu$-opioid receptor expression in metastatic lung cancer. Br J Anaesth 113 (Suppl 1): i103-i108, 2014.

24. Lennon FE, Mirzapoiazova T, Mambetsariev B, Salgia R, Moss J and Singleton PA: Overexpression of the $\mu$-opioid receptor in human non-small cell lung cancer promotes Akt and mTOR activation, tumor growth, and metastasis. Anesthesiology 116 857-867, 2012

25. Wolff RF, Aune D, Truyers C, Hernandez AV, Misso K, Riemsma R and Kleijnen J: Systematic review of efficacy and safety of buprenorphine versus fentanyl or morphine in patients with chronic moderate to severe pain. Curr Med Res Opin 28 : 833-845, 2012

26. Cieślińska A, Sienkiewicz-Szłapka E, Kostyra E, Fiedorowicz E, Snarska J, Wroński K, Tenderenda M, Jarmołowska B and Matysiewicz M: $\mu$-Opioid receptor gene (OPRM1) polymorphism in patients with breast cancer. Tumour Biol 36 4655-4660, 2015.

27. Singleton PA, Moss J, Karp DD, Atkins JT and Janku F: The mu opioid receptor: A new target for cancer therapy? Cancer 121: 2681-2688, 2015.

28. Steele GL, Dudek AZ, Gilmore GE, Richter SA, Olson DA, Eklund JP and Zylla DM: Impact of pain, opioids, and the mu-opioid receptor on progression and survival in patients with newly diagnosed stage IV pancreatic cancer. Am J Clin Oncol 43: $591-597,2020$

29. Kim J, Ham S, Hong H, Moon C and Im HI: Brain reward circuits in morphine addiction. Mol Cells 39: 645-653, 2016.

30. Benyamin R, Trescot AM, Datta S, Buenaventura R, Adlaka R, Sehgal N, Glaser SE and Vallejo R: Opioid complications and side effects. Pain Physician 11 (Suppl 2): S105-S120, 2008.
31. Bodnar RJ: Endogenous opioid modulation of food intake and body weight: Implications for opioid influences upon motivation and addiction. Peptides 116: 42-62, 2019.

32. Bagley EE and Ingram SL: Endogenous opioid peptides in the descending pain modulatory circuit. Neuropharmacology 173: 108131, 2020

33. Barron BA: Opioid peptides and the heart. Cardiovasc Res 43: 13-16, 1999.

34. Gein SV and Baeva TA: Endogenous opioid peptides in regulation of innate immunity cell functions. Biochemistry (Mosc) 76 309-319, 2011.

35. Mercadante $\mathrm{S}$ and Romualdi $\mathrm{P}$ : The therapeutic potential of nove kappa opioid receptor-based treatments. Curr Med Chem 27: 2012-2020, 2020

36. Waldhoer M, Bartlett SE and Whistler JL: Opioid receptors Annu Rev Biochem 73: 953-990, 2004.

37. Minami M, Toya T, Katao Y, Maekawa K, Nakamura S, Onogi T, Kaneko $\mathrm{S}$ and Satoh M: Cloning and expression of a cDNA for the rat kappa-opioid receptor. FEBS Lett 329: 291-295, 1993.

38. Schoffelmeer AN, Hogenboom F and Mulder AH: Kappa1- and kappa2-opioid receptors mediating presynaptic inhibition of dopamine and acetylcholine release in rat neostriatum. $\mathrm{Br}$ J Pharmacol 122: 520-524, 1997

39. Brooks AI, Standifer KM, Rossi GC, Mathis JP and Pasternak GW: Characterizing kappa3 opioid receptors with a selective monoclonal antibody. Synapse 22: 247-252, 1996.

40. Cahill CM, Taylor AM, Cook C, Ong E, Morón JA and Evans CJ: Does the kappa opioid receptor system contribute to pain aversion? Front Pharmacol 5: 253, 2014.

41. Crowley NA and Kash TL: Kappa opioid receptor signaling in the brain: Circuitry and implications for treatment. Prog Neuropsychopharmacol Biol Psychiatry 62: 51-60, 2015.

42. Ruan X, Mancuso KF and Kaye AD: Revisiting oxycodone analgesia: A review and hypothesis. Anesthesiol Clin 35: e163-e174, 2017.

43. Schmidt-Hansen M, Bennett MI, Arnold S, Bromham N and Hilgart JS: Oxycodone for cancer-related pain. Cochrane Database Syst Rev 8: Cd003870, 2017.

44. Jin WQ, Tai KK, Chan TK and Wong TM: Further characterization of $[3 \mathrm{H}] \mathrm{U} 69593$ binding sites in the rat heart. J Mol Cell Cardiol 27: 1507-1511, 1995.

45. Simonin F, Gavériaux-Ruff C, Befort K, Matthes H, Lannes B, Micheletti G, Mattéi MG, Charron G, Bloch B and Kieffer B: kappa-Opioid receptor in humans: cDNA and genomic cloning, chromosomal assignment, functional expression, pharmacology, and expression pattern in the central nervous system. Proc Nat Acad Sci USA 92: 7006-7010, 1995.

46. Gavériaux-Ruff C, Peluso J, Befort K, Simonin F, Zilliox C and Kieffer BL: Detection of opioid receptor mRNA by RT-PCR reveals alternative splicing for the delta- and kappa-opioid receptors. Brain Res Mol Brain Res 48: 298-304, 1997.

47. Wang YJ, Rasakham K, Huang P, Chudnovskaya D, Cowan A and Liu-Chen LY: Sex difference in $\kappa$-opioid receptor (KOPR)-mediated behaviors, brain region KOPR level and KOPR-mediated guanosine 5'-O-(3-[35S]thiotriphosphate) binding in the guinea pig. J Pharmacol Exp Ther 339: 438-450, 2011

48. Machelska $\mathrm{H}$ and Celik M: Opioid receptors in immune and glial cells-implications for pain control. Front Immunol 11: 300, 2020

49. Spasov AA, Grechko O and Shtareva DM: Kappa-opioid receptor: Molecular structure and function. Eksp klin Farmakol 77: 27-35, 2014 (In Russian).

50. Carroll FI and Carlezon WA Jr: Development of $\kappa$ opioid receptor antagonists. J Med Chem 56: 2178-2195, 2013.

51. Yamamizu K, Hamada Y and Narita M: $\kappa$ Opioid receptor ligands regulate angiogenesis in development and in tumours. $\mathrm{Br}$ J Pharmacol 172: 268-276, 2015

52. Shi Y, Luo J, Tian J,Zou Q and Wang X: The kappa opioid receptor may be a potential tumor suppressor by regulating angiogenesis in breast cancer. Med Hypotheses 150: 110568, 2021.

53. Wigmore T and Farquhar-Smith P: Opioids and cancer: Friend or foe? Curr Opin Support Palliat Care 10: 109-118, 2016.

54. Strang P: Cancer pain-a provoker of emotional, social and existential distress. Acta Oncol 37: 641-644, 1998.

55. Reiche EM, Nunes SO and Morimoto HK: Stress, depression, the immune system, and cancer. Lancet Oncol 5: 617-625, 2004.

56. Edwards KA, Havelin JJ, McIntosh MI, Ciccone HA, Pangilinan K, Imbert I, Largent-Milnes TM, King T, Vanderah TW and Streicher JM: A kappa opioid receptor agonist blocks bone cancer pain without altering bone loss, tumor size, or cancer cell proliferation in a mouse model of cancer-induced bone pain. J Pain 19: 612-625, 2018 
57. Zhang YF, Xu QX, Liao LD, Xu XE, Wu JY, Shen J, Wu ZY, Shen JH, Li EM and Xu LY: $\kappa-O p i o i d$ receptor in the nucleus is a novel prognostic factor of esophageal squamous cell carcinoma. Hum Pathol 44: 1756-1765, 2013.

58. Diao CT, Li L, Lau SY, Wong TM and Wong NS: kappa-Opioid receptor potentiates apoptosis via a phospholipase $\mathrm{C}$ pathway in the CNE2 human epithelial tumor cell line. Biochim Biophys Acta 1499: 49-62, 2000.

59. Li H, Ma Z and Lei Y: The expression of kappa-opioid receptor promotes the migration of breast cancer cells in vitro. BMC Anesthesiol 21: 210, 2021.

60. Chen D, Chen Y, Yan Y, Pan J, Xing W, Li Q and Zeng W: Down-regulation of the tumour suppressor $\kappa$-opioid receptor predicts poor prognosis in hepatocellular carcinoma patients. BMC Cancer 17: 553, 2017.

61. Tripolt S, Neubauer HA, Knab VM, Elmer DP, Aberger F, Moriggl R and Fux DA: Opioids drive breast cancer metastasis through the $\delta$-opioid receptor and oncogenic STAT3. Neoplasia 23: 270-279, 2021.

62. Brejchova J, Holan V and Svoboda P: Expression of opioid receptors in cells of the immune system. Int J Mol Sci 22: 315, 2020.

63. Pert CB and Snyder SH: Opiate receptor: Demonstration in nervous tissue. Science 179: 1011-1014, 1973

64. Kiguchi N, Ding H, Kishioka S and Ko MC: Nociceptin/orphanin FQ peptide receptor-related ligands as novel analgesics. Curr Top Med Chem 20: 2878-2888, 2020.

65. Dhaliwal A and Gupta M: Physiology, opioid receptor. In: StatPearls (Internet). StatPearls Publishing, Treasure Island, FL, 2021.

66. Valentino RJ and Volkow ND: Untangling the complexity of opioid receptor function. Neuropsychopharmacology 43: 2514-2520, 2018.

67. Chavkin C, James IF and Goldstein A: Dynorphin is a specific endogenous ligand of the kappa opioid receptor. Science 215: 413-415, 1982.

68. Bruchas MR, Land BB and Chavkin C: The dynorphin/kappa opioid system as a modulator of stress-induced and pro-addictive behaviors. Brain Res 1314: 44-55, 2010.

69. Terenius L: From opiate pharmacology to opioid peptide physiology. Ups J Med Sci 105: 1-15, 2000.

70. Goldstein A and Naidu A: Multiple opioid receptors: Ligand selectivity profiles and binding site signatures. Mol Pharmacol 36: 265-272, 1989.

71. Giros B, Pohl M, Rochelle JM and Seldin MF: Chromosomal localization of opioid peptide and receptor genes in the mouse. Life Sci 56: PL369-PL375, 1995.

72. Wei LN and Loh HH: Transcriptional and epigenetic regulation of opioid receptor genes: Present and future. Annu Rev Pharmacol Toxicol 51: 75-97, 2011.

73. Xie GX, Meng F, Mansour A, Thompson RC, Hoversten MT Goldstein A, Watson SJ and Akil H: Primary structure and functional expression of a guinea pig kappa opioid (dynorphin) receptor. Proc Natl Acad Sci USA 91: 3779-3783, 1994.

74. Wu H, Wacker D, Mileni M, Katritch V, Han GW, Vardy E, Liu W, Thompson AA, Huang XP, Carroll FI, et al: Structure of the human $\kappa$-opioid receptor in complex with JDTic. Nature 485: 327-332, 2012.

75. Akil $\mathrm{H}$ and Watson SJ: Cloning of kappa opioid receptors: Functional significance and future directions. Prog Brain Res 100: 81-86, 1994.

76. Law PY, Loh HH and Wei LN: Insights into the receptor transcription and signaling: Implications in opioid tolerance and dependence. Neuropharmacology 47 (Suppl 1): S300-S311, 2004.

77. Al-Hasani R and Bruchas MR: Molecular mechanisms of opioid receptor-dependent signaling and behavior. Anesthesiology 115: 1363-1381, 2011

78. Bruchas MR, Xu M and Chavkin C: Repeated swim stress induces kappa opioid-mediated activation of extracellular signal-regulated kinase 1/2. Neuroreport 19: 1417-1422, 2008.

79. Kam AY, Chan AS and Wong YH: Kappa-opioid receptor signals through Src and focal adhesion kinase to stimulate c-Jun N-terminal kinases in transfected COS-7 cells and human monocytic THP-1 cells. J Pharmacol Exp Ther 310: 301-310, 2004.

80. Finley MJ, Steele A, Cornwell WD and Rogers TJ: Transcriptional regulation of the major HIV-1 coreceptor, CXCR4, by the kappa opioid receptor. J Leukoc Biol 90: 111-121, 2011.

81. Georgoussi Z, Georganta EM and Milligan G: The other side of opioid receptor signalling: Regulation by protein-protein interaction. Curr Drug Targets 13: 80-102, 2012.
82. Fink RM and Gallagher E: Cancer pain assessment and measurement. Semin Oncol Nurs 35: 229-234, 2019.

83. Wiffen PJ, Cooper TE, Anderson AK, Gray AL, Grégoire MC, Ljungman $\mathrm{G}$ and Zernikow B: Opioids for cancer-related pain in children and adolescents. Cochrane Database Syst Rev 7: Cd012564, 2017.

84. Wiffen PJ, Wee B, Derry S, Bell RF and Moore RA: Opioids for cancer pain-an overview of cochrane reviews. Cochrane Database Syst Rev 7: Cd012592, 2017.

85. Paton KF, Atigari DV, Kaska S, Prisinzano T and Kivell BM: Strategies for developing $\kappa$ opioid receptor agonists for the treatment of pain with fewer side effects. J Pharmacol Exp Ther 375: 332-348, 2020.

86. Escobar ADP, Casanova JP, Andrés ME and Fuentealba JA: Crosstalk between kappa opioid and dopamine systems in compulsive behaviors. Front Pharmacol 11: 57, 2020.

87. McLaughlin JP, Li S, Valdez J, Chavkin TA and Chavkin C: Social defeat stress-induced behavioral responses are mediated by the endogenous kappa opioid system. Neuropsychopharmacology 31: 1241-1248, 2006.

88. Knoll AT and Carlezon WA Jr: Dynorphin, stress, and depression. Brain Res 1314: 56-73, 2010.

89. Carlezon WA Jr and Krystal AD: Kappa-Opioid antagonists for psychiatric disorders: From bench to clinical trials. Depress Anxiety 33: 895-906, 2016.

90. Falcon E, Maier K, Robinson SA, Hill-Smith TE and Lucki I: Effects of buprenorphine on behavioral tests for antidepressant and anxiolytic drugs in mice. Psychopharmacology (Berl) 232: 907-915, 2015

91. Ahmadi J, Jahromi MS and Ehsaei Z: The effectiveness of different singly administered high doses of buprenorphine in reducing suicidal ideation in acutely depressed people with co-morbid opiate dependence: A randomized, double-blind, clinical trial. Trials 19: 462, 2018.

92. Serafini G, Adavastro G, Canepa G, De Berardis D, Valchera A, Pompili M, Nasrallah $\mathrm{H}$ and Amore M: The efficacy of buprenorphine in major depression, treatment-resistant depression and suicidal behavior: A systematic review. Int J Mol Sci 19: 2410, 2018

93. Wang Q, Long Y, Hang A, Zan GY, Shu XH, Wang YJ and Liu JG: The anxiolytic- and antidepressant-like effects of ATPM-ET, a novel $\kappa$ agonist and $\mu$ partial agonist, in mice. Psychopharmacology (Berl) 233: 2411-2418, 2016.

94. Kovalska M, Kovalska L, Tothova B, Mahmood S, Adamkov M and Lehotsky J: Combination of hyperhomocysteinemia and ischemic tolerance in experimental model of global ischemia in rats. J Physiol Pharmacol 66: 887-897, 2015.

95. Dennis TS, Beck KD, Cominski TP, Bobzean SAM, Kuzhikandathil EV, Servatius RJ and Perrotti LI: Exposure to morphine-associated cues increases mu opioid receptor mRNA expression in the nucleus accumbens of Wistar Kyoto rats. Behav Brain Res 313: 208-213, 2016.

96. Menyhárt Á, Makra P, Szepes BE, Tóth OM, Hertelendy P, Bari F and Farkas E: High incidence of adverse cerebral blood flow responses to spreading depolarization in the aged ischemic rat brain. Neurobiol Aging 36: 3269-3277, 2015.

97. Chen C, Xi C, Liang X, Ma J, Su D, Abel T and Liu R: The role of $\kappa$ opioid receptor in brain ischemia. Crit Care Med 44: e1219-e1225, 2016.

98. Sobanski P, Krajnik M, Shaqura M, Bloch-Boguslawska E, Schäfer M and Mousa SA: The presence of mu-, delta-, and kappa-opioid receptors in human heart tissue. Heart Vessels 29: 855-863, 2014.

99. Jaiswal A, Kumar S, Seth S, Dinda AK and Maulik SK: Effect of U50,488H, a $\kappa$-opioid receptor agonist on myocardial $\alpha$-and $\beta$-myosin heavy chain expression and oxidative stress associated with isoproterenol-induced cardiac hypertrophy in rat. Mol Cell Biochem 345: 231-240, 2010.

100. Komaba H, Moriwaki K, Goto S, Yamada S, Taniguchi M, Kakuta T, Kamae I and Fukagawa M: Cost-effectiveness of cinacalcet hydrochloride for hemodialysis patients with severe secondary hyperparathyroidism in Japan. Am J Kidney Dis 60: 262-271, 2012.

101. Wang H, Wang JL, Ren HW, He WF and Sun M: Butorphanol protects on myocardial ischemia/reperfusion injury in rats through MAPK signaling pathway. Eur Rev Med Pharmacol Sci 23: 10541-10548, 2019.

102. Brust TF, Morgenweck J, Kim SA, Rose JH, Locke JL, Schmid CL, Zhou L, Stahl EL, Cameron MD, Scarry SM, et al: Biased agonists of the kappa opioid receptor suppress pain and itch without causing sedation or dysphoria. Sci Signal 9: ra117, 2016. 
103. Feng Y, He X, Yang Y, Chao D, Lazarus LH and Xia Y: Current research on opioid receptor function. Curr Drug Targets 13: 230-246, 2012.

104. Bray F, Ferlay J, Soerjomataram I, Siegel RL, Torre LA and Jemal A: Global cancer statistics 2018: GLOBOCAN estimates of incidence and mortality worldwide for 36 cancers in 185 countries. CA Cancer J Clin 68: 394-424, 2018

105. Llovet JM, Zucman-Rossi J, Pikarsky E, Sangro B, Schwartz M, Sherman M and Gores G: Hepatocellular carcinoma. Nat Rev Dis Primers 2: 16018, 2016.

106. DeSantis CE, Lin CC, Mariotto AB, Siegel RL, Stein KD, Kramer JL, Alteri R, Robbins AS and Jemal A: Cancer treatment and survivorship statistics, 2014. CA Cancer J Clin 64 252-271, 2014

107. Maneckjee R and Minna JD: Opioid and nicotine receptors affect growth regulation of human lung cancer cell lines. Proc Natl Acad Sci USA 87: 3294-3298, 1990

108. Kuzumaki N, Suzuki A, Narita M, Hosoya T, Nagasawa A, Imai S, Yamamizu K, Morita H, Nagase H, Okada Y, et al: Effect of $\kappa$-opioid receptor agonist on the growth of non-small cell lung cancer (NSCLC) cells. Br J Cancer 106: 1148-1152, 2012

109. Sim EH, Yang IA, Wood-Baker R, Bowman RV and Fong KM: Gefitinib for advanced non-small cell lung cancer. Cochrane Database Syst Rev 1: CD006847, 2018

110. Bareschino MA, Schettino C, Troiani T, Martinelli E, Morgillo F and Ciardiello F: Erlotinib in cancer treatment. Ann Oncol 18 (Suppl 6): vi35-vi41, 2007.

111. Rho JK, Choi YJ, Ryoo BY, Na III, Yang SH, Kim CH and Lee JC: p53 enhances gefitinib-induced growth inhibition and apoptosis by regulation of Fas in non-small cell lung cancer. Cancer Res 67: 1163-1169, 2007.

112. An WF, Germain AR, Bishop JA, Nag PP, Metkar S, Ketterman J, Walk M, Weiwer M, Liu X, Patnaik D, et al: Discovery of potent and highly selective inhibitors of GSK3b. In: Probe Reports from the NIH Molecular Libraries Program. National Center for Biotechnology Information (US), Bethesda (MD), 2010.

113. Tian D, Zhu M, Chen WS, Li JS, Wu RL and Wang X: Role of glycogen synthase kinase 3 in squamous differentiation induced by cigarette smoke in porcine tracheobronchial epithelial cells. Food Chem Toxicol 44: 1590-1596, 2006.

114. Zheng H, Saito H, Masuda S, Yang X and Takano Y: Phosphorylated GSK3beta-ser9 and EGFR are good prognostic factors for lung carcinomas. Anticancer Res 27: 3561-3569, 2007

115. Oren M: Decision making by p53: Life, death and cancer. Cell Death Differ 10: 431-442,2003.

116. Gao S, Brown J, Wang H and Feng X: The role of glycogen synthase kinase 3- $\beta$ in immunity and cell cycle: Implications in esophagea cancer. Arch Immunol Ther Exp (Warsz) 62: 131-144, 2014.

117. Maneckjee R, Biswas R and Vonderhaar BK: Binding of opioids to human MCF-7 breast cancer cells and their effects on growth Cancer Res 50: 2234-2238, 1990

118. Hatzoglou A, Bakogeorgou E and Castanas E: The antiproliferative effect of opioid receptor agonists on the T47D human breast cancer cell line, is partially mediated through opioid receptors. Eur J Pharmacol 296: 199-207, 1996.

119. Montagna G, Gupta HV, Hannum M, Tan KS, Lee J, Scarpa JR, Plitas G, Irie T, McCormick PJ, Fischer GW, et al: Intraoperative opioids are associated with improved recurrence-free survival in triple-negative breast cancer. Br J Anaesth 126: 367-376, 2021.

120. Abnet CC, Arnold M and Wei WQ: Epidemiology of esophageal squamous cell carcinoma. Gastroenterology 154: 360-373, 2018

121. Zylla D, Gourley BL, Vang D, Jackson S, Boatman S, Lindgren B, Kuskowski MA, Le C, Gupta K and Gupta P: Opioid requirement, opioid receptor expression, and clinical outcomes in patients with advanced prostate cancer. Cancer 119: 4103-4110, 2013

122. Harper P, Hald O, Lwaleed BA, Kyyaly A, Johnston D, Cooper AJ and Birch B: The impact of morphine treatment on bladder cancer cell proliferation and apoptosis: In vitro studies. Exp Oncol 40: 190-193, 2018.

123. Moon TD: The effect of opiates upon prostatic carcinoma cell growth. Biochem Biophys Res Commun 153: 722-727, 1988.

124. Kampa M, Bakogeorgou E, Hatzoglou A, Damianaki A, Martin PM and Castanas E: Opioid alkaloids and casomorphin peptides decrease the proliferation of prostatic cancer cell lines (LNCaP, PC3 and DU145) through a partial interaction with opioid receptors. Eur J Pharmacol 335: 255-265, 1997.

125. Kampa M, Loukas S, Tsapis A and Castanas E: Receptorphin A conserved peptide derived from the sequence of the opioid receptor, with opioid displacement activity and potent antiproliferative actions in tumor cells. BMC Pharmacol 1: 9,2001.
126. Yamashita H, Shuman L, Warrick JI, Raman JD and Degraff DJ: Androgen represses opioid growth factor receptor (OGFR) in human prostate cancer LNCaP cells and OGFR expression in human prostate cancer tissue. Am J Clin Exp Urol 6: 164-171, 2018.

127. Lec PM, Lenis AT, Golla V, Brisbane W, Shuch, Garraway IP, Reiter RE and Chamie K: The role of opioids and their receptors in urological malignancy: A review. J Urol 204: 1150-1159, 2020.

128. Goodenberger ML and Jenkins RB: Genetics of adult glioma. Cancer Genet 205: 613-621, 2012.

129. Bohn LM, Belcheva MM and Coscia CJ: Evidence for kappa- and mu-opioid receptor expression in C6 glioma cells. J Neurochem 70: 1819-1825, 1998

130. Remmers AE, Clark MJ, Mansour A, Akil H, Woods JH and Medzihradsky F: Opioid efficacy in a C6 glioma cell line stably expressing the human kappa opioid receptor. J Pharmacol Exp Ther 288: 827-833, 1999.

131. Giakoumettis D, Kritis A and Foroglou N: C6 cell line: The gold standard in glioma research. Hippokratia 22: 105-112, 2018.

132. Bohn LM, Belcheva MM and Coscia CJ: Mitogenic signaling via endogenous kappa-opioid receptors in C6 glioma cells: Evidence for the involvement of protein kinase $\mathrm{C}$ and the mitogen-activated protein kinase signaling cascade. J Neurochem 74: 564-573, 2000.

133. Bohn LM, Belcheva MM and Coscia CJ: Mu-opioid agonist inhibition of kappa-opioid receptor-stimulated extracellular signal-regulated kinase phosphorylation is dynamin-dependent in C6 glioma cells. J Neurochem 74: 574-581, 2000.

134. Kampa M, Margioris AN, Hatzoglou A, Dermitzaki I, Denizot A, Henry JF, Oliver C, Gravanis A and Castanas E: Kappa1-opioid binding sites are the dominant opioid binding sites in surgical specimens of human pheochromocytomas and in a human pheochromocytoma (KAT45) cell line. Eur J Pharmacol 364: 255-262, 1999 .

135. Venihaki M, Gravanis A and Margioris AN: Kappa opioids exert a strong antiproliferative effect on PC12 rat pheochromocytoma cells. Peptides 17: 413-419, 1996.

136. Takekoshi K, Ishii K, Kawakami Y, Isobe K and Nakai T: kappa-Opioid inhibits catecholamine biosynthesis in PC12 rat pheochromocytoma cell. FEBS Lett 477: 273-277, 2000.

137. Chatzaki E, Margioris AN, Makrigiannakis A, Castanas E, Georgoulias V and Gravanis A: Kappa opioids and TGFbeta1 interact in human endometrial cells. Mol Hum Reprod 6: 602-609, 2000.

138. Li WW, Zhao WJ, Yang Y and Yang YM: Effects of TGF- $\beta 1$ on the expression of endometrial stromal cell-related protein and mRNA. Eur Rev Med Pharmacol Sci 24: 11475-11480, 2020.

139. Chatzaki E, Kouimtzoglou E, Margioris AN and Gravanis A: Transforming growth factor beta1 exerts an autocrine regulatory effect on human endometrial stromal cell apoptosis, involving the FasL and Bcl-2 apoptotic pathways. Mol Hum Reprod 9: $91-95,2003$

140. Chamouard P, Klein A, Martin E, Adloff M and Angel F: Regulatory role of enteric kappa opioid receptors in human colonic motility. Life Sci 53: 1149-1156, 1993

141. Sherman SK, Maxwell JE, Carr JC, Wang D, Bellizzi AM, O'Dorisio MS, O'Dorisio TM and Howe JR: Gene expression accurately distinguishes liver metastases of small bowel and pancreas neuroendocrine tumors. Clin Exp Metastasis 31: 935-944, 2014

142. Li T, Kang G, Wang T and Huang H: Tumor angiogenesis and anti-angiogenic gene therapy for cancer. Oncol Lett 16: 687-702, 2018.

143. Mody K, Baldeo C and Bekaii-Saab T: Antiangiogenic therapy in colorectal cancer. Cancer J 24: 165-170, 2018.

144. Al-Husein B, Abdalla M, Trepte M, Deremer DL and Somanath PR: Antiangiogenic therapy for cancer: An update. Pharmacotherapy 32: 1095-1111, 2012.

145. Carmeliet P: VEGF as a key mediator of angiogenesis in cancer. Oncology 69 (Suppl 3): S4-S10, 2005.

146. Olejarz W, Kubiak-Tomaszewska G, Chrzanowska A and Lorenc T: Exosomes in angiogenesis and anti-angiogenic therapy in cancers. Int J Mol Sci 21: 5840, 2020.

147. Pujade-Lauraine E, Hilpert F, Weber B, Reuss A Poveda A, Kristensen G, Sorio R, Vergote I, Witteveen P, Bamias A, et al: Bevacizumab combined with chemotherapy for platinum-resistant recurrent ovarian cancer: The AURELIA open-label randomized phase III trial. J Clin Oncol 32: 1302-1308, 2014 
148. Heinemann V, von Weikersthal LF, Decker T, Kiani A, Vehling-Kaiser U, Al-Batran SE, Heintges T, Lerchenmüller C, Kahl C, Seipelt G, et al: FOLFIRI plus cetuximab versus FOLFIRI plus bevacizumab as first-line treatment for patients with metastatic colorectal cancer (FIRE-3): A randomised, open-label, phase 3 trial. Lancet Oncol 15: 1065-1075, 2014.

149. Rini BI, Bellmunt J, Clancy J, Wang K, Niethammer AG, Hariharan S and Escudier B: Randomized phase III trial of temsirolimus and bevacizumab versus interferon alfa and bevacizumab in metastatic renal cell carcinoma: INTORACT trial. J Clin Oncol 32: 752-759, 2014.

150. Bear HD, Tang G, Rastogi P, Geyer CE Jr, Liu Q, Robidoux A, Baez-Diaz L, Brufsky AM, Mehta RS, Fehrenbacher L, et al: Neoadjuvant plus adjuvant bevacizumab in early breast cancer [NSABP B-40 (NRG Oncology)]: Secondary outcomes of a phase 3, randomised controlled trial. Lancet Oncol 16: 1037-1048, 2015.

151. Yamamizu K, Furuta S, Hamada Y, Yamashita A, Kuzumaki N, Narita M, Doi K, Katayama S, Nagase H, Yamashita JK and Narita M: к Opioids inhibit tumor angiogenesis by suppressing VEGF signaling. Sci Rep 3: 3213, 2013.

152. Yamamizu K and Yamashita JK: Roles of cyclic adenosine monophosphate signaling in endothelial cell differentiation and arterial-venous specification during vascular development. Circ J 75: 253-260, 2011.

153. Singh N, Baby D, Rajguru JP, Patil PB, Thakkannavar SS and Pujari VB: Inflammation and cancer. Ann Afr Med 18: 121-126, 2019.

154. Elinav E, Nowarski R, Thaiss CA, Hu B, Jin C and Flavell RA Inflammation-induced cancer: Crosstalk between tumours, immune cells and microorganisms. Nat Rev Cancer 13: 759-771, 2013.

155. Chuang TK, Killam KF Jr, Chuang LF, Kung HF, Sheng WS, Chao CC, Yu L and Chuang RY: Mu opioid receptor gene expression in immune cells. Biochem Biophys Res Commun 216: 922-930, 1995.

156. Kao TK, Ou YC, Liao SL, Chen WY, Wang CC, Chen SY, Chiang $\mathrm{AN}$ and Chen $\mathrm{CJ}$ : Opioids modulate post-ischemic progression in a rat model of stroke. Neurochem Int 52: 1256-1265, 2008.

157. Zhang P, Yang M, Chen C, Liu L, Wei X and Zeng S: Toll-Like receptor 4 (TLR4)/opioid receptor pathway crosstalk and impact on opioid analgesia, immune function, and gastrointestinal motility. Front Immunol 11: 1455, 2020.

158. Eisenstein TK: The role of opioid receptors in immune system function. Front Immunol 10: 2904, 2019.

159. Finley MJ, Happel CM, Kaminsky DE and Rogers TJ: Opioid and nociceptin receptors regulate cytokine and cytokine receptor expression. Cell Immunol 252: 146-154, 2008.

160. Multhoff $G$ and Vaupel P: Hypoxia compromises anti-cancer immune responses. Adv Exp Med Biol 1232: 131-143, 2020.

161. Dehne N, Mora J, Namgaladze D, Weigert A and Brüne B: Cancer cell and macrophage cross-talk in the tumor microenvironment. Curr Opin Pharmacol 35: 12-19, 2017.

162. Xi C, Liang X, Chen C, Babazada H, Li T and Liu R: Hypoxia induces internalization of $\kappa$-opioid receptor. Anesthesiology 126: 842-854, 2017.

163. BabcockJ,Herrera A, CoricorG, Karch C,Liu AH,Rivera-Gines A and Ko JL: Mechanism governing human kappa-opioid receptor expression under desferrioxamine-induced hypoxic mimic condition in neuronal NMB cells. Int J Mol Sci 18: 211, 2017.

164. Brownstein MJ: A brief history of opiates, opioid peptides, and opioid receptors. Proc Natl Acad Sci USA 90: 5391-5393, 1993.

165. Meuser T, Pietruck C, Radbruch L, Stute P, Lehmann KA and Grond S: Symptoms during cancer pain treatment following WHO-guidelines: A longitudinal follow-up study of symptom prevalence, severity and etiology. Pain 93: 247-257, 2001

166. Zylla D, Steele G and Gupta P: A systematic review of the impact of pain on overall survival in patients with cancer. Support Care Cancer 25: 1687-1698, 2017

167. Boland JW and Pockley AG: Influence of opioids on immune function in patients with cancer pain: From bench to bedside. $\mathrm{Br}$ J Pharmacol 175: 2726-2736, 2018.

168. Juneja R: Opioids and cancer recurrence. Curr Opin Support Palliat Care 8: 91-101, 2014.

169. Amaram-Davila J, Davis M and Reddy A: Opioids and cancer mortality. Curr Treat Options Oncol 21: 22, 2020.

170. Fujiwara Y, Yamamoto $\mathrm{H}$ and Monden $\mathrm{M}$ : Molecular biology-based surgery for the future progress of cancer treatment. Nihon Geka Gakkai Zasshi 103: 278-283, 2002 (In Japanese).
171. Hashizume $\mathrm{M}$ and Tsugawa K: Robotic surgery and cancer: The present state, problems and future vision. Jpn J Clin Oncol 34: 227-237, 2004

172. Baskar R, Lee KA, Yeo R and Yeoh KW: Cancer and radiation therapy: Current advances and future directions. Int J Med Sci 9: 193-199, 2012.

173. Lee YT, Tan YJ and Oon CE: Molecular targeted therapy: Treating cancer with specificity. Eur J Pharmacol 834: 188-196, 2018.

174. Cross D and Burmester JK: Gene therapy for cancer treatment: Past, present and future. Clin Med Res 4: 218-227, 2006.

175. Chen WK and Miao CH: The effect of anesthetic technique on survival in human cancers: A meta-analysis of retrospective and prospective studies. PLoS One 8: e56540, 2013

176. Gach K, Wyrebska A, Fichna J and Janecka A: The role of morphine in regulation of cancer cell growth. Naunyn Schmiedebergs Arch Pharmacol 384: 221-230, 2011.

177. Forget P, Aguirre JA, Bencic I, Borgeat A, Cama A, Condron C, Eintrei C, Eroles P, Gupta A, Hales TG, et al: How anesthetic, analgesic and other non-surgical techniques during cancer surgery might affect postoperative oncologic outcomes: A summary of current state of evidence. Cancers (Basel) 11: 592, 2019.

178. Liu B, Liu Y, Li N, Zhang J and Zhang X: Oxycodone regulates incision-induced activation of neurotrophic factors and receptors in an acute post-surgery pain rat model. J Pain Res 11: 2663-2674, 2018.

179. Ji J, Lin W, Vrudhula A, Xi J, Yeliseev A, Grothusen JR, Bu W and Liu R: Molecular interaction between butorphanol and к-opioid receptor. Anesth Analg 131: 935-942, 2020.

180. Tian M, Jin L, Li R, Zhu S, Ji M and Li W: Comparison of oxycodone and morphine on the proliferation, apoptosis and expression of related molecules in the A549 human lung adenocarcinoma cell line. Exp Ther Med 12: 559-566, 2016.

181. Yu Y, Li D, Duan J, Xu H, Li L, Tan D and Yan H: The pro- and anti-cancer effects of oxycodone are associated with epithelial growth factor receptor level in cancer cells. Biosci Rep 40: BSR20193524, 2020

182. Gery S, Yin D, Xie D, Black KL and Koeffler HP: TMEFF1 and brain tumors. Oncogene 22: 2723-2727, 2003.

183. Nie X, Gao L, Zheng M, Wang C, Wang S, Li X, Qi Y, Zhu L, Liu J and Lin B: Overexpression of TMEFF1 in endometrial carcinoma and the mechanism underlying its promotion of malignant behavior in cancer cells. J Cancer 12: 5772-5788, 2021 .

184. Nie X, Liu C, Guo Q, Zheng MJ, Gao LL, Li X, Liu DW, Zhu LC, Liu JJ and Lin B: TMEFF1 overexpression and its mechanism for tumor promotion in ovarian cancer. Cancer Manag Res 11: 839-855, 2019.

185. Wang B, Li Y, Shen Y, Xu Y and Zhang C: Butorphanol inhibits the malignant biological behaviors of ovarian cancer cells via down-regulating the expression of TMEFF1. Onco Targets Ther 13: 10973-10981, 2020.

186. Ramirez MF, Gorur A and Cata JP: Opioids and cancer prognosis: A summary of the clinical evidence. Neurosci Lett 746 : 135661, 2021.

187. Wang YH, Sun JF, Tao YM, Chi ZQ and Liu JG: The role of kappa-opioid receptor activation in mediating antinociception and addiction. Acta Pharmacol Sin 31: 1065-1070, 2010.

188. Torre LA, Siegel RL, Ward EM and Jemal A: Global cancer incidence and mortality rates and trends-an update. Cancer Epidemiol Biomarkers Prev 25: 16-27, 2016.

189. Ramirez MF, Gorur A and Cata JP: The role of opioids in cancer progression. Int Anesthesiol Clin Spring 58: 57-63, 2020.

190. Rodrigue D, Winkelmann J, Price M, Kalandranis E, Klempner L and Kapoor-Hintzen N: Opioid misuse: An organizational response while managing cancer-related pain. Clin J Oncol Nurs 24: 170-176, 2020.

191. Schmidhammer H, Erli F, Guerrieri E and Spetea M: Development of diphenethylamines as selective kappa opioid receptor ligands and their pharmacological activities. Molecules 25: 5092, 2020. International (CC BY-NC-ND 4.0) License. 